\title{
Endocrine Signals Altered by Heat Stress Impact Dairy Cow Mammary Cellular Processes at Different Stages of the Dry Period
}

\author{
Véronique Ouellet ${ }^{1}{ }^{1}$, João Negrao ${ }^{1,2} \oplus$, Amy L. Skibiel ${ }^{1,+}{ }^{\dagger}$, Valerie A. Lantigua ${ }^{1}$, Thiago F. Fabris ${ }^{1}(\mathbb{D}$, \\ Marcela G. Marrero ${ }^{1}$, Bethany Dado-Senn ${ }^{1, \ddagger}$, Jimena Laporta ${ }^{1, \ddagger}$ and Geoffrey E. Dahl ${ }^{1, *}$ \\ 1 Department of Animal Sciences, University of Florida, Gainesville, FL 32611, USA; \\ veronique.ouellet.6@ulaval.ca (V.O.); jnegrao@usp.br (J.N.); askibiel@uidaho.edu (A.L.S.); \\ vlantigua@ufl.edu (V.A.L.); tfabris89@gmail.com (T.F.F.); marcela.marrero@ufl.edu (M.G.M.); \\ bethanydado@ufl.edu (B.D.-S.); jlaporta@wisc.edu (J.L.) \\ 2 Department of Basic Sciences, Faculty of Animal Science and Food Engineering, University of Sao Paulo, \\ Pirassununga, SP 05508-270, Brazil \\ * Correspondence: gdahl@ufl.edu; Tel.: +1-352-294-6980; Fax: +1-352-392-5595 \\ + Current address: Department of Animal and Veterinary Science, University of Idaho, Moscow, ID 83844, USA \\ $\ddagger$ Current address: Department of Animal and Dairy Sciences, University of Wisconsin-Madison, \\ Madison, WI 53706, USA.
}

check for updates

Citation: Ouellet, V.; Negrao, J.; Skibiel, A.L.; Lantigua, V.A.; Fabris, T.F.; Marrero, M.G.; Dado-Senn, B.; Laporta, J.; Dahl, G.E. Endocrine Signals Altered by Heat Stress Impact Dairy Cow Mammary Cellular Processes at Different Stages of the Dry Period. Animals 2021, 11, 563. https://doi.org/10.3390/ani11020563

Academic Editors: Jong-Eun Park and Himansu Kumar

Received: 12 January 2021

Accepted: 15 February 2021

Published: 21 February 2021

Publisher's Note: MDPI stays neutral with regard to jurisdictional claims in published maps and institutional affiliations.

Copyright: (c) 2021 by the authors. Licensee MDPI, Basel, Switzerland. This article is an open access article distributed under the terms and conditions of the Creative Commons Attribution (CC BY) license (https:/ / creativecommons.org/licenses/by/ $4.0 /)$.
Simple Summary: Late-gestation heat stress increases blood prolactin and decreases oestrogen concentrations in dry cows. These hormonal alterations may disturb mammary gland remodelling during the dry period, thereby being potentially responsible for the observed production impairments during the subsequent lactation. This project aimed to better understand the molecular mechanisms underlying subsequent impairments in mammary performance after dry period heat stress. For this, we studied the expression of genes encompassing prolactin and oestrogen pathways and key cellular process pathways under different thermal environments and in vitro hormonal milieus. The results of this study revealed that late-gestation heat stress impacted the expression of genes in the mammary gland involved in key cellular processes occurring during the dry period. Furthermore, our results indicated that these modifications are in part modulated by alterations of oestrogen and prolactin signalling.

Abstract: Hormonal alterations occurring under late gestation heat stress may disturb mammary gland remodelling, resulting in a reduced milk yield during the subsequent lactation. We investigated the effects of an altered endocrine environment on mammary gene expression at different stages of the dry period. Mammary gland biopsies from in vivo-cooled (CL) or heat-stressed (HT) cows were collected at $\mathrm{d} 3$ and 35 relative to dry-off and divided into explants. Explants were incubated in vitro for $24 \mathrm{~h}$ in one of three media: Basal: no prolactin or estrogen; CL-mimic: Basal + low prolactin + high $17 \beta$-estradiol, or HT-mimic: Basal + high prolactin + low 17 $\beta$-estradiol. Real time qPCR was used to quantify gene expression. We established that late-gestation heat stress changes the expression of prolactin and oestrogen receptors, downregulates genes involved in apoptosis, autophagy and proliferation at $\mathrm{d} 3$ and upregulates genes related to those cellular processes at $\mathrm{d} 35$. Moreover, compared with in vivo treatments, we showed that the expression of fewer genes was impacted by in vitro treatments which aimed to mimic the hormonal response of cows exposed to a different environment. Further research will continue to uncover the mechanisms behind the production impairments caused by late-gestation heat stress.

Keywords: apoptosis; autophagy; hormones; gene expression

\section{Introduction}

During the lactation cycle, the mammary gland undergoes a series of cyclical developmental changes. In dairy cows, the dry period, a non-lactating state that connects successive lactations, typically last 60 days and involve both a far-off and a close-up period 
that begins 3 weeks before expected calving. The dry period is important for the removal of senescent mammary cells and their regrowth before parturition [1,2]. It can be functionally divided into two phases: mammary involution, which is rapidly initiated after cessation of milk removal, and the subsequent mammary growth until calving [3]. Intracellular processes such as apoptosis [4,5] and autophagy [6] facilitate cell turnover during mammary involution, whereas mammary growth is driven by accelerated cell proliferation. Once lactation begins, the overall capacity of the mammary gland to synthesize and store milk depends on the dynamic equilibrium between cell turnover and proliferation established during the functional phases of the dry period [2].

Dry period heat stress undermines production in dairy cows $[7,8]$. Subsequent milk yield losses of $10 \%$ (3.6 kg/d; reviewed by Ouellet et al. [9]) are observed when cows are exposed to heat stress during the last two months of gestation. However, the underlying biological mechanisms of this decline are not yet fully elucidated. Potential explanations for the impaired mammary gland development in heat-stressed dry cows include reduced gestation length which may lead to lower milk outputs during early lactation [10,11], limited nutrient availability due to decreased dry matter intake [12,13] and redistributed blood flow to the periphery [14]. However, other factors related to altered endocrine signalling and immune function due to heat stress may also play a role in mammary cell turnover and proliferation. Circulating prolactin (PRL) concentrations increase, whereas estrone sulphate (E) concentrations decrease in cows exposed to hyperthermia during the dry period [15-17]. Several lines of evidence indicate that these two hormones can blunt mammary gland remodelling, as PRL serves as an anti-apoptotic factor in mammary tissue [18], whereas oestrogen promotes both autophagy and proliferation [19,20]. However, the relationship of these endocrine mechanisms to heat stress-induced shifts in mammary development is yet to be determined.

Although studies have revealed that mammary tissue from heat-stressed dry cows has lower expression of autophagy and apoptosis markers during involution [21-23], much remains to be understood about the effects of heat stress on mammary gland development during different stages of the dry period. Herein, we investigated the impact of different thermal environment and altered endocrine signals on expression of genes involved in PRL and E signalling, autophagy, apoptosis, and proliferation, using mammary tissue explants collected from heat-stressed and cooled dry cows during the early and late dry period. We hypothesized that heat stress-driven disturbances in hormone concentrations would alter the expression of genes involved in mammary cell autophagy, apoptosis, and proliferation during the dry period.

\section{Materials and methods}

\subsection{Animals and Experimental Design}

The experiment was conducted between May and November 2018 at the University of Florida Dairy Unit in Hague, FL, USA. All procedures were approved by the University of Florida Institutional Animal Care and Use Committee.

The experimental design for this study follows that described in Fabris et al. [23]. Briefly, twenty multiparous lactating Holstein dairy cows housed in a sand-bedded freestall barn were dried off at $\sim 45$ days prior to expected calving date based on standard operating procedures at the University of Florida Dairy Unit. Cows were randomly assigned to one of two in vivo treatments: heat stress (HT; only provided shade of the barn) or cooling (CL; provided shade of the barn and active cooling by fans and soakers), based on parity and mature equivalent milk production of the previous lactation. All cows were fed a common total mixed ration ad libitum formulated to meet the nutrient requirements of dairy cows based on Nutrient Requirements of Dairy Cattle (NRC) [24] recommendations. All cows had access to water at all times.

\subsection{Indicators of Heat Stress}

Air temperature and relative humidity of both sides of the barn were recorded every 15 min by using Hobo Pro series temp probes (Onset Computer Corp., Pocasset, MA, USA). 
From these variables, daily temperature-humidity index (THI) was calculated following the equation developed by the National Research Council (NRC) [25] and recommended for use in subtropical environments by Dikmen and Hansen [26]:

$$
T H I=(1.8 \times T+32)-[(0.55-0.0055 \times R H)+(1.8 \times T-26)]
$$

where $T=$ dry bulb temperature $\left({ }^{\circ} \mathrm{C}\right)$ and $R H=$ relative humidity $(\%)$.

Vaginal temperature $\left({ }^{\circ} \mathrm{C}\right)$ and respiration rate (breaths/min) were also measured in all cows to confirm that cows were exposed to heat stress. Blank controlled internal drug release devices were fitted with a temperature probe (i-button cat. \#DS1922-F5, accuracy $\pm 0.0625^{\circ} \mathrm{C}$; Maxim, Irving, TX, USA) and inserted vaginally to measure vaginal temperatures every $10 \mathrm{~min}$ and averaged hourly, as described by Fabris et al. [23]. Respiration rates were measured by counting flank movements for $1 \mathrm{~min}$, as described by Dado-Senn et al. [27].

\subsection{Mammary Biopsies and Tissue Explant Processing}

Mammary biopsies were collected on d 3 (early mammary involution) and 35 (mammary redevelopment phase) relative to dry-off from a subset of seven cows per treatment (Figure 1). This sample size was calculated based on the mammary cell proliferation data obtained in the late dry period from heat-stressed or cooled cows [7] using a level of significance of 0.05 and $85 \%$ power. Mammary biopsies were taken from the right or left rear quarters of the udder, alternating sides for each biopsy time point following the method described by Skibiel et al. [28].

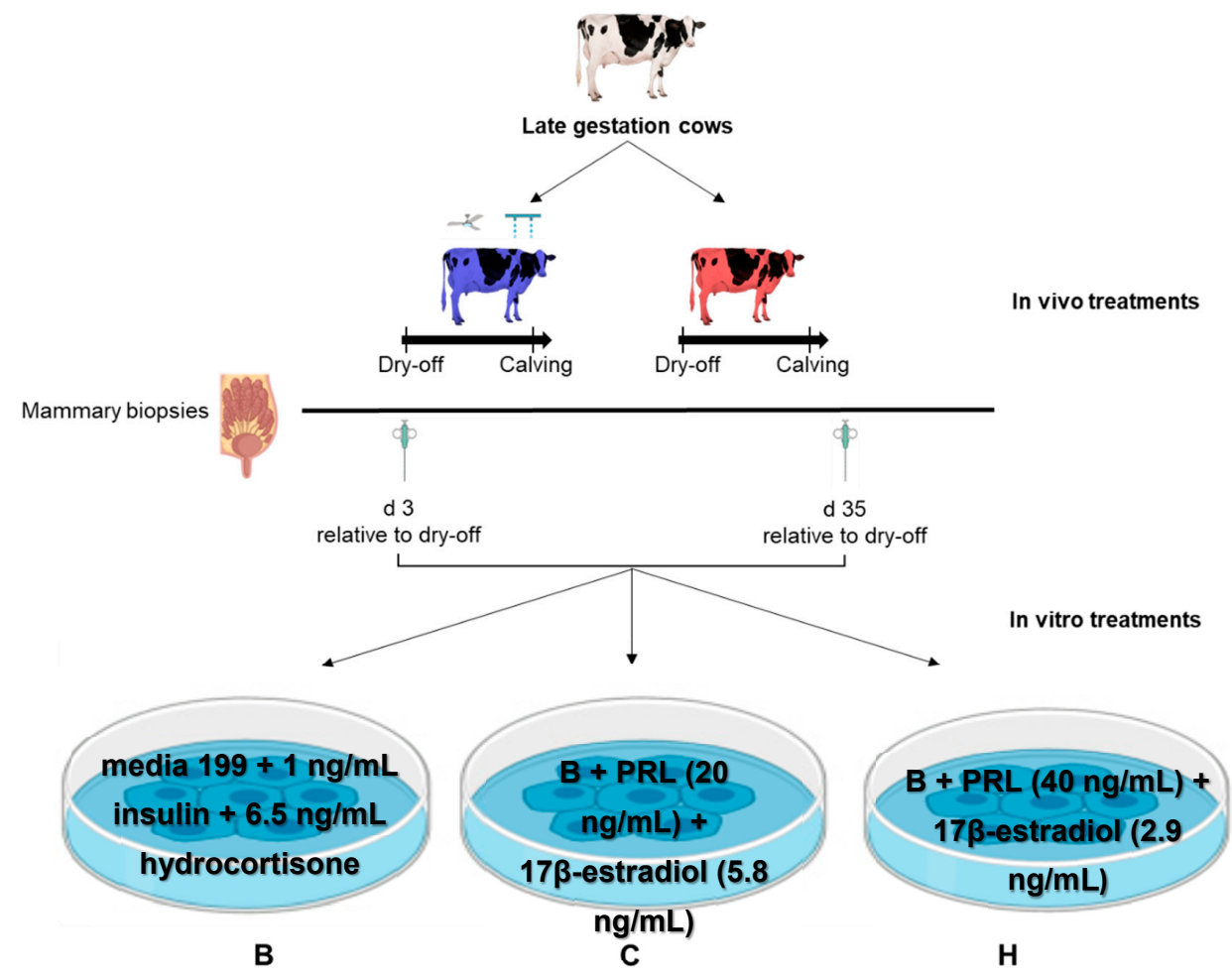

Figure 1. Schematic representation of the experimental design presented in the current study. Late gestation cows were dried off at $46 \mathrm{~d}$ before calving and assigned to 1 of 2 in vivo treatments: cooling (CL) $(n=7)$; provided shade of the barn and active cooling by soakers and fans (blue); heat treatment (HT) ( $n=7)$; only provided shade of the barn (red). Mammary biopsies were collected at $3 \mathrm{~d}$ (to capture the involution phase) and 35 (to capture the mammary redevelopment phase) and tissue explants were incubated in 1 of 3 in vitro treatments: (1) Basal (B): no prolactin or oestrogen; (2) CL-mimic (C): B $+20 \mathrm{ng} / \mathrm{mL}$ prolactin $+5.8 \mathrm{ng} / \mathrm{mL}$ oestrogen or (3) HT-mimic $(\mathbf{H}): \mathrm{B}+40 \mathrm{ng} / \mathrm{mL}$ prolactin $+2.9 \mathrm{ng} / \mathrm{mL}$ oestrogen . 
Mammary explants were prepared and cultured following procedures by Accorsi et al. [18] and by De Vries et al. [29] with modifications. Briefly, after biopsy, tissues were placed in sterilized, cold Medium 199 containing gentamicin $(50 \mu \mathrm{g} / \mathrm{mL})$, penicillin $(100 \mathrm{IU} / \mathrm{mL})$ and streptomycin $(100 \mu \mathrm{g} / \mathrm{mL})$, and immediately cut into small $(<2 \mathrm{~mm})$ pieces. After rinsing with sterilized Phosphate-buffered saline solution (PBS) containing amphotericin B $(1.5 \mu \mathrm{g} / \mathrm{mL})$, penicillin $(100 \mathrm{IU} / \mathrm{mL})$ and streptomycin $(100 \mu \mathrm{g} / \mathrm{mL})$, approximately $100 \mathrm{mg}$ of explant were then placed in cell culture inserts $(8.0 \mu \mathrm{m}$ pore size) in a multi-well plate and cultured in a humidified chamber $\left(95 \%\right.$ air and $\left.5 \% \mathrm{CO}_{2}\right)$ at $38.5^{\circ} \mathrm{C}$ for $24 \mathrm{~h}$ in each of the following 3 media (in vitro treatments): (1) basal media (B): Medium 199 supplemented with $1 \mathrm{ng} / \mathrm{mL}$ bovine insulin (Sigma \#I6634), and $6.5 \mathrm{ng} / \mathrm{mL}$ hydrocortisone (Sigma \#H0888); (2) media (C) to mimic the hormone combination of CL cows: B + ovine pituitary PRL $(20 \mathrm{ng} / \mathrm{mL}$, Prospec-Tany Technogene, Ltd., Ness-Ziona, Israel, \#cyt-240) + 17ß-estradiol (5.8 ng/mL, Sigma \#E2758); and $(3)$ media $(\mathrm{H})$ that mimics the hormone combination of HT cows: B + ovine pituitary PRL $(40 \mathrm{ng} / \mathrm{mL})+17 \beta$-estradiol $(2.9 \mathrm{ng} / \mathrm{mL})$.

The incubation temperature was selected based on thermoneutral cow body temperature to mimic the CL environment in vivo; and an incubation time of $24 \mathrm{~h}$ has proven reasonable to effectively induce cellular events by addition of hormones in a mammary explant culture system [18]. The hormonal concentrations in media C or $\mathrm{H}$ were selected based on previously published data $[8,15,16,30]$ to mimic the endocrine profile in the blood of CL and HT dry cows, respectively.

\subsection{Lactate Dehydrogenase Activity Analysis}

When disease or injury damages tissue, cells release LDH, which can therefore serve as index of cell injury and death. To verify that tissue was viable after the $24 \mathrm{~h}$ incubation, lactate dehydrogenase (LDH) activity was evaluated in: (1) media deprived of cells (B media only), (2) B media containing mammary tissue explants, and (3) B media containing $0.1 \%$ Triton- $X$ with tissue explants. Explants with Triton- $X$ were incubated at room temperature for $24 \mathrm{~h}$ and served as a positive control for maximum LDH release. Lactate dehydrogenase activity was measured in the media using a colorimetric assay kit according to the manufacturer's instructions (BioVision, Milpitas, CA, USA). Media were harvested after the $24 \mathrm{~h}$ incubation and assayed immediately after. Plates were read at an absorbance at $450 \mathrm{~nm}$ before and after a $30 \mathrm{~min}$ incubation at $37^{\circ} \mathrm{C}$. The basis of this test is a coupled enzymatic reaction in which $\mathrm{LDH}$ present within the sample catalyses the reversible conversion of lactate into pyruvate with the concomitant reduction of NAD+ to NADH, which then interacts with a probe to produce a colour signal in proportion to LDH activity.

\subsection{Explant RNA Extraction}

Total RNA was isolated from the tissue using a Qiagen RNA extraction (RNeasy Plus Universal Mini Kit, Qiagen, cat. \#73404, Venlo, The Netherlands) following the manufacturer's instructions. The concentration and quality of extracted RNA was then determined by spectrophotometry using a NanoDrop (NanoDrop ${ }^{\mathrm{TM}}$ Spectrophotometer, Thermo Scientific, Waltham, MA, USA; \#ND-2000). The concentration of total RNA ranged from 6.9 to $816.6 \mathrm{ng} / \mu \mathrm{L}$, with an average $( \pm \mathrm{SD})$ of $151.4 \pm 118.9 \mathrm{ng} / \mu \mathrm{L}$. The RNA was considered of sufficient purity for further analysis if the $260 \mathrm{~nm}: 280 \mathrm{~nm}$ ratio was $>1.80$ (Thermo Scientific, Waltham, MA, USA). Samples were stored at $-80^{\circ} \mathrm{C}$ until further analysis.

\subsection{Gene Expression Analysis}

The expression of genes related to PRL and E pathways, apoptosis, autophagy, cell proliferation, inflammation, immunity, branching morphogenesis, and heat shock response was quantified in tissue explants. For this, high-throughput Multiplex RT-qPCR BioMark Dynamic Array Integrated Fluidic Circuits (IFCs) were used (Fluidigm Corporation, San Francisco, CA, USA). Briefly, 96 primers targeting 91 genes of interest, 4 reference genes, namely beta actin $(A C T B)$, glyceraldehyde 3-phosphate dehydrogenase (GADPH), ribosomal protein S9 (RSP9) and hypoxanthine phosphoribosyltransferase 1 (HPRT1) and one 
structural reference gene were assayed (Supplemental Material Table S1). Targeted genes were selected to feature key genes in pathways that could be affected by the altered hormonal milieu caused by heat stress. Primers were designed using publicly available bovine gene sequences from the National Center for Biotechnology Information gene database (http: / / www.ncbi.nlm.nih.gov, accessed on 11 September 2019).

The RNA of tissue explants was diluted to $6 \mathrm{ng} / \mu \mathrm{L}$. As previously described by Marrero et al. [31], all samples were normalized to $256 \mathrm{pg}$ RNA and transferred to the IFC plate with the primer-probe sets. All nanolitre reactions were performed as per manufacturer's recommendations using the following thermal protocol: $95{ }^{\circ} \mathrm{C}$ for $1 \mathrm{~min}$, followed by 30 cycles of $96^{\circ} \mathrm{C}$ for $5 \mathrm{~s}$ and $60{ }^{\circ} \mathrm{C}$ for $20 \mathrm{~s}$. The software Fluidigm RealTime PCR Analysis was used to calculate Ct values for all 96 genes for each sample. Non-detectable expression was set at a Ct of 28.92 .

Relative quantification was achieved using the delta $\mathrm{Ct}(\Delta \mathrm{Ct})$ method [32]. The stability of the housekeeping genes was tested using geNorm. The program indicated that $A C T B, R S P 9$ and HPRT1 were the most stable genes. Therefore, the geometric mean of the $\mathrm{Ct}$ values of these three most stable reference genes was calculated, and the target assay $\mathrm{Ct}$ values were made relative to the geometric mean of reference genes $(\Delta \mathrm{Ct})$. Normalized gene expression $(\Delta \mathrm{Ct})$ was used for gene expression statistical analysis.

\subsection{Principal Component Analysis}

Principal component analysis (PCA) expresses data to highlight their similarities and differences without much loss of information [33] and was herein performed to test whether the principal components (PC) would cluster according to biopsy time (i.e., mammary involution or redevelopment), gene function (where relative gene expression was averaged by function: heat shock, PRL and E signalling, cell proliferation, autophagy, apoptosis, immunity/inflammation, branching morphogenesis) or treatments (in vivo or in vitro).

\subsection{Statistical Analyses}

All statistical analyses were performed in SAS (version 9.4, SAS Institute, Inc., Cary, NC, USA). Data were first tested for covariance (Levene's test) and normality of distribution was tested by evaluating Shapiro-Wilk statistics using the univariate procedure. Differences in THI were analysed by pen using a generalized linear mixed model with the main effects of treatment, day (repeated measure), and their interaction. Respiration rate and rectal temperature were analysed with the MIXED procedure with the main effects of treatment (CL, HT), and day (repeated) and cow ID nested within treatments as a random effect. Differences in LDH activity were analysed with PROC GLM with treatments as a fixed effect.

Normalized gene expression $(\Delta \mathrm{Ct})$ at mammary involution and mammary redevelopment phase was evaluated separately. The model included in vivo treatment (CL or HT), in vitro treatments $(B, C, H)$ and their interaction as fixed effects. $p$ values $\leq 0.05$ were considered statistically significant and $p$-values $\leq 0.15$ were considered a trend toward significance. The estimates of the model for each gene were then used to calculate fold change $(\Delta \Delta \mathrm{Ct})$. To evaluate the effects of the in vivo treatments (CL, HT) on gene expression, the fold change relative to the CL cows $(\Delta \Delta \mathrm{Ct})$ was calculated as shown in Equation [1]:

$$
\Delta \Delta \mathrm{Ct}(\text { in vivo })=2-(\Delta \mathrm{Ct} H \mathrm{H}-\Delta \mathrm{Ct} \mathrm{CL}) .
$$

To evaluate the effects of the in vitro treatments $(B, C$ and $H)$ on gene expression, the fold change relative to mRNA abundance quantified in explants cultures in media B was calculated as shown in Equations (2) and (3):

$$
\begin{aligned}
& \Delta \Delta \mathrm{Ct} \text { (in vitro })=2-(\Delta \mathrm{Ct} \mathrm{C}-\Delta \mathrm{Ct} \mathrm{B}) . \\
& \Delta \Delta \mathrm{Ct}(\text { in vitro })=2-(\Delta \mathrm{Ct} \mathrm{H}-\Delta \mathrm{Ct} \mathrm{B}) .
\end{aligned}
$$




\section{Results}

\subsection{Thermal Environment and Physiological Parameters In Vivo}

Throughout the dry period, THI measurements recorded at the experimental pens level were similar between CL and HT treatments (78.21 vs. $78.76 \pm 0.25, p=0.24)$. However, relative to $\mathrm{HT}, \mathrm{CL}$ cows had $\mathrm{X}{ }^{\circ} \mathrm{C}$ lower vaginal temperatures ( 38.9 vs. $39.2 \pm 0.2^{\circ} \mathrm{C}$, $p<0.01$ ). Additionally, $\mathrm{CL}$ cows had lower respiration rates compared to their HT counterparts ( 54.6 vs. $65.3 \pm 1.2$ breaths $/ \mathrm{min}, p<0.05$ ).

\subsection{Lactate Dehydrogenase Activity In Vitro}

Lactate dehydrogenase activity $(\mathrm{mmol} / \mathrm{min} / \mathrm{mL})$ was lower in B media deprived of tissue explants relative to when mammary tissue explants were incubated in B media (0.11 vs. $2.54 \pm 0.4 \mathrm{mmol} / \mathrm{min} / \mathrm{mL} ; p<0.05$; Figure 2$)$. Higher LDH activity $(\mathrm{mmol} / \mathrm{min} / \mathrm{mL})$ was observed in cells incubated in B media with $0.1 \%$ Triton-X (Thermo Fisher Scientific Inc., Waltham, MA, USA), which served as the maximum release sample, compared with tissue explants incubated in the B media (6.06 vs. $2.54 \pm 0.7 \mathrm{mmol} / \mathrm{min} / \mathrm{mL} ; p<0.05$; Figure 2).

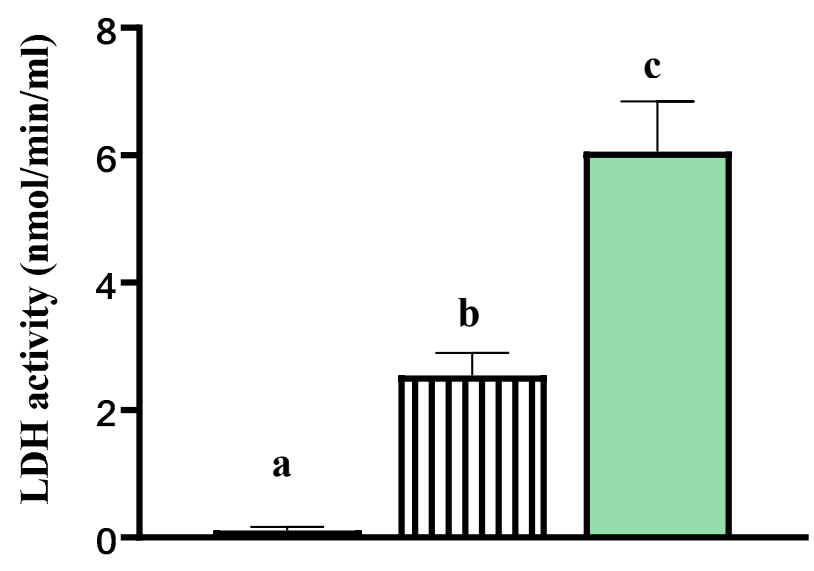

Figure 2. Lactate dehydrogenase $(\mathrm{LDH})$ activity $(\mathrm{mmol} / \mathrm{min} / \mathrm{mL})$ from basal media alone (

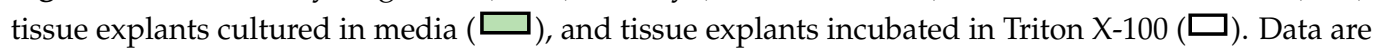
presented as least square means \pm standard error of the mean (SEM) Different letters a-c indicate $p$-value $<0.05$. LDH activity was higher in the media of explants incubated in Triton X-100 at room temperature relative to both the media from tissue explants cultured in vitro and relative to the basal media deprived of tissue explants. This indicated that cells within the explants cultured in vitro for $24 \mathrm{~h}$ were viable.

\subsection{Principal Component Analysis}

The PCA demonstrated that the expression of mammary tissue harvested during early mammary involution and mammary redevelopment clustered distinctively (Figure 3a). The first two PC explained $60 \%$ of total variation ( $40 \%$ and $20 \%$ for PC1 and PC2, respectively) when the statistical analysis of differences in gene expression was performed by biopsy time point separately. Furthermore, when the relative expression of genes was averaged by functional pathway, the PCA loading plot showed that the relative gene expression clustered by gene function, where the first two PCs explained 80\% of total variation (53\% and $27 \%$ for PC1 and PC2, respectively) (Figure 3b). Finally, when averaged by treatments, the PCA indicated that relative expression clustered by in vivo and in vitro treatments with the first two PC explained 58\% of total variation (38\% and $20 \%$ for PC1 and PC2, respectively) (Figure 3c). 

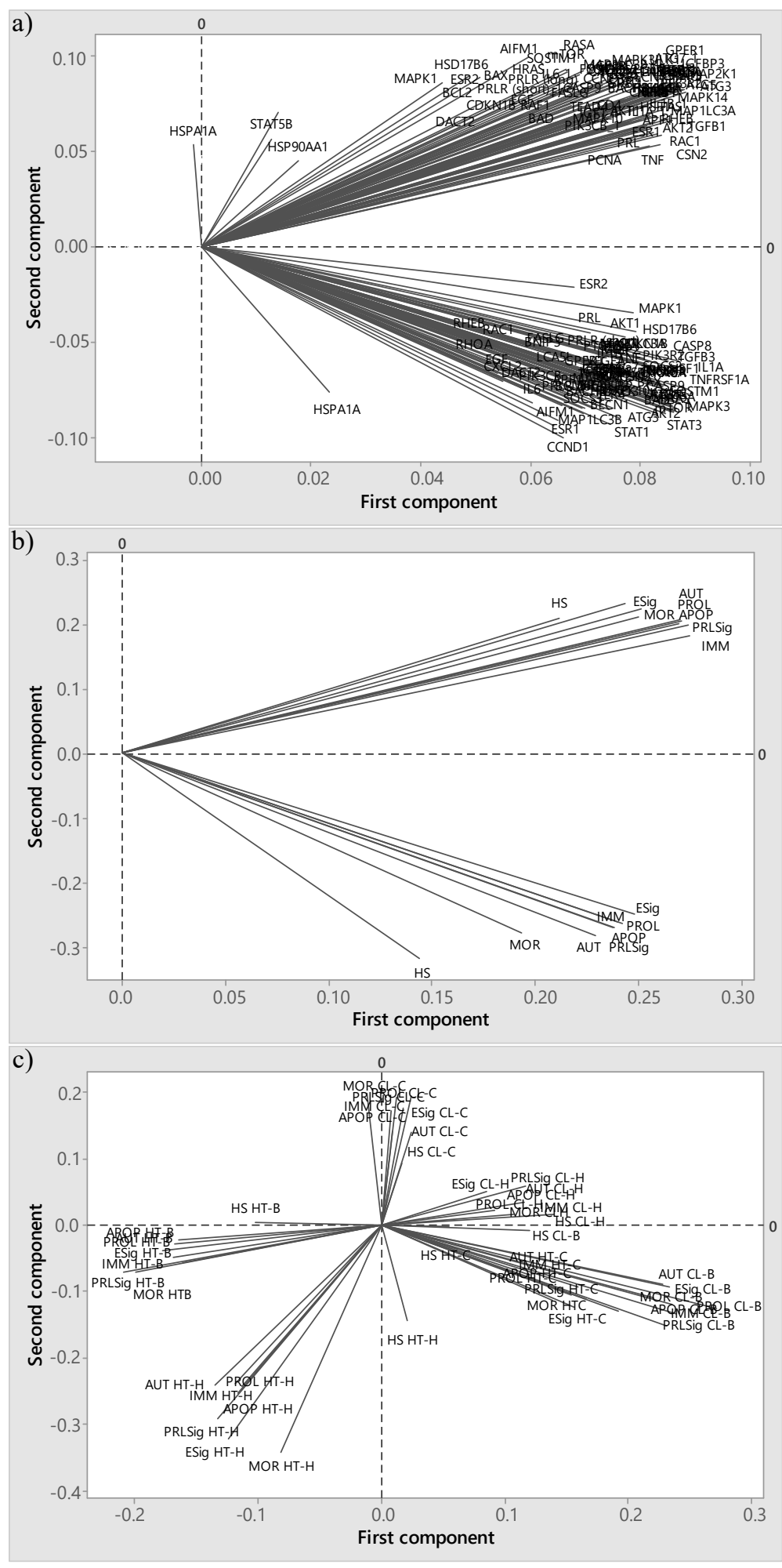

Figure 3. Loading plots describing relationships between: (a) mammary gland relative expression of 91 genes (as detailed in Table S1) and biopsy collection time point, (b) gene functions: heat shock (HS), prolactin signalling (PRLSig), oestrogen signalling (ESig), cell proliferation (PROL), autophagy (AUT), apoptosis (APOP), morphology (MOR), and immunity (IMM), and (c) in vivo and in vitro treatments from a principal component analysis. Figure $3 \mathrm{c}$ included genes averaged heat shock (HS), prolactin signalling (PRLSig), oestrogen signalling (ESig), cell proliferation (PROL), autophagy (AUT), apoptosis (APOP), morphology (MOR), and immunity (IMM), by in vivo and in vitro treatments CL-H, CL-C, CL-B, HT-H, HT-C, and HT-B. 


\subsection{Effects of In Vivo Thermal Environment on Mammary Gland Gene Expression}

Heat exposure during the dry period impacted the expression of prolactin receptor long form (PRLR long; $p=0.02)$, serine/threonine kinase B-raf $(B R A F ; p=0.09)$ and oestrogen receptor $2(E S R 2 ; p=0.04)$ as those genes involved in PRL and $E$ signalling tended to be or was upregulated in HT explants compared to CL explants during mammary involution (Figure $4 \mathrm{a}, \mathrm{c})$. During mammary redevelopment, PRLR long was upregulated, whereas RAS p21 protein activator 1 (RASA1), BRAF, and ESR2 tended to be or were downregulated in HT explants relative to CL explants (Figure $4 \mathrm{a}, \mathrm{c}$, all $p \leq 0.10$ ).

a)

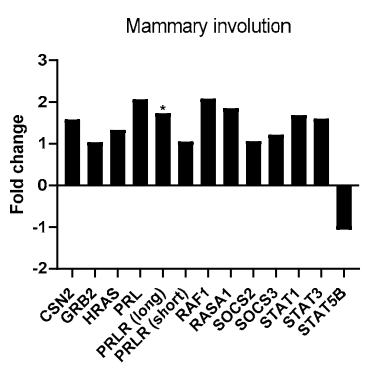

Mammary redevelopment
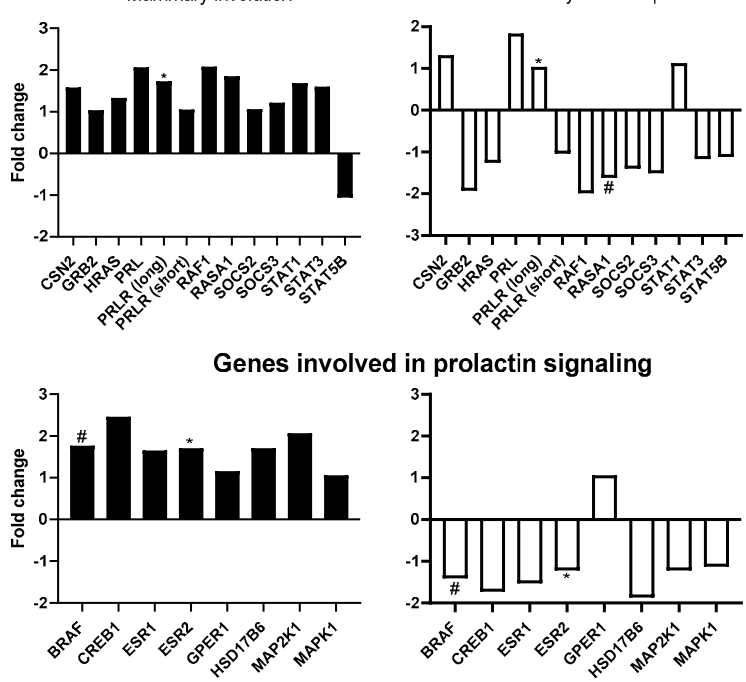

e)

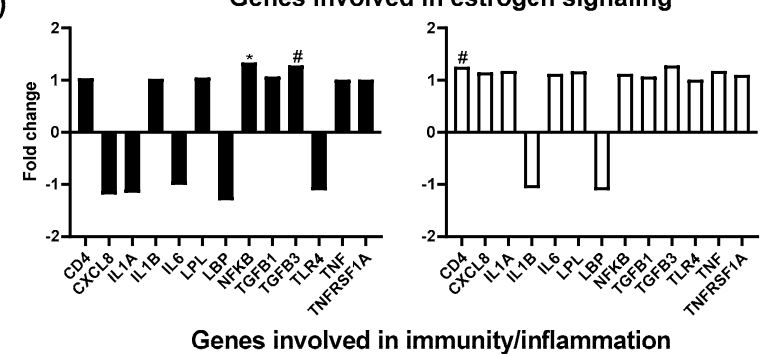

g)

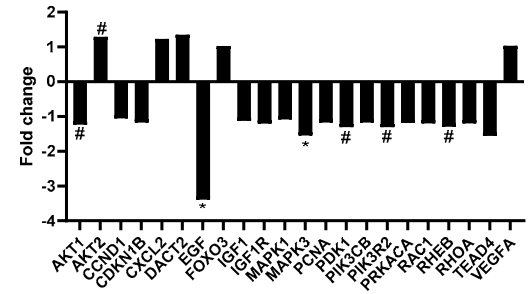

b)

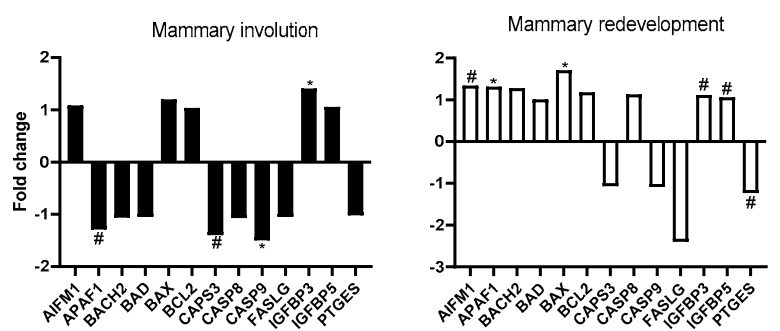

d)

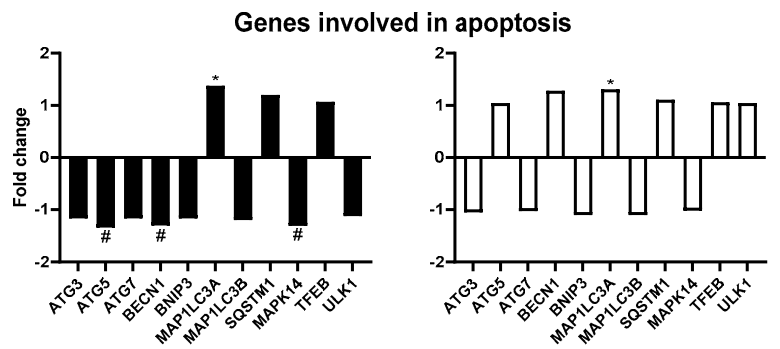

f)
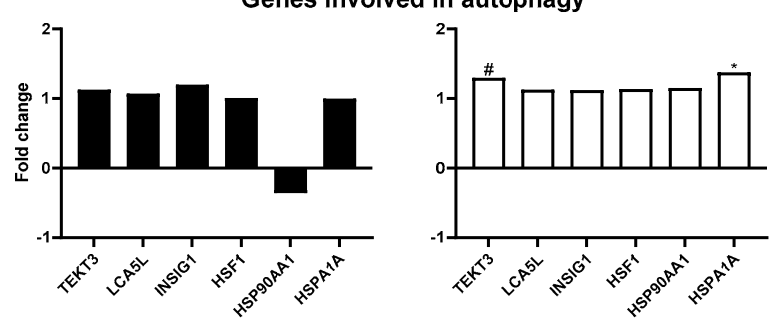

Genes involved in morphogenesis and heat stress

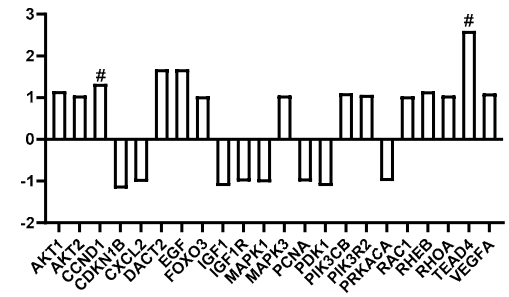

Genes involved in proliferation

Figure 4. Gene expression in mammary gland tissue explants of heat-stressed dairy cows (HT) or cows provided active cooling (CL) during the dry period. Explants were collected during early involution (black columns, $3 \mathrm{~d}$ after dry off) and during mammary growth (white columns, $35 \mathrm{~d}$ after dry off) phases. Gene expression is reported as fold change $\left(2^{-\Delta \Delta \mathrm{Ct}}\right)$ relative to cooled cows. An asterisk $\left(^{*}\right)$ indicates significant differences $(p \leq 0.05)$ and (\#) indicates tendencies $(0.05<p \leq 0.15)$ between HT and CL treatments. $(\mathbf{a}-\mathbf{g})$ refer to the gene function of interest.

Heat stress exposure during the dry period altered the expression of 9 out of the 13 apoptosis-related genes evaluated (Figure $4 \mathrm{~b}$ ). For example, in vivo heat stress exposure downregulated or tended to downregulate the expression of Apoptotic peptidase activating factor 1 (APAF1; $p=0.15)$, Caspase 3 (CASP3; $p=0.07)$, Caspase 9 (CASP9; $p=0.05)$ during mammary involution, whereas insulin-like growth factor binding protein 
3 (IGFPB3; $p=0.05$ ) was upregulated. During the mammary redevelopment phase, the gene expression of apoptosis inducing factor mitochondria associated $1($ AIFM1; $p=0.06)$, APAF1 $(p=0.05)$, apoptosis regulator BAX (BAX; $p=0.01)$, IGFBP3 $(p=0.05)$, and insulinlike growth factor binding protein 5 (IGFBP5; $p=0.12$ ) tended to be or were upregulated, whereas the expression of prostaglandin E synthase (PTGES; $p=0.14)$ tended to be downregulated in HT explants relative to CL explants.

The thermal environment to which the animals were subjected during the dry period also impacted the gene expression of 4 out of 11 autophagy-related genes analysed (Figure 4d). During mammary involution, Autophagy related AGT5 (ATG5; $p=0.15$ ) and Beclin 1 (BECN1) tended $(p=0.07)$ to be downregulated, whereas microtubule-associated protein 1 light chain 3 beta $(M A P 1 L C 3 A)$ was upregulated $(p=0.02)$ in HT explants relative to $C L$ explants. Furthermore, during the mammary redevelopment phase, MAP1LC $3 A$ was upregulated $(p=0.01)$ in HT explants.

Few immune related genes in the mammary tissue were impacted by the thermal environment. Specifically, nuclear factor-kappa B $(N F-\kappa B ; p=0.05)$ was, and transforming growth factor beta 3 (TGFB3; $p=0.07$ ) tended to be upregulated in HT explants during mammary involution, whereas CD4 molecule $(C D 4 ; p=0.12)$ tended to be upregulated during mammary redevelopment phase. Moreover, heat shock response related gene heat shock protein family A HSP70 (HSPA1A; $p=0.02)$ and ductal branching-related gene Tektin 3 (TEKT3; $p=0.07$ ) were respectively upregulated or tended to be upregulated in HT explants during mammary redevelopment (Figure 4f).

Heat stress exposure during the dry period also impacted the expression of 9 out of 22 genes involved in cell proliferation evaluated herein (Figure 4g). More specifically, AKT serine/threonine kinase $2(A K T 2 ; p=0.08)$ tended to be upregulated during early mammary involution, whereas epidermal growth factor $(E G F ; p=0.10)$, mitogen-activated protein kinase $3(M A P K 3 ; p=0.04)$, pyruvate dehydrogenase 1 (PDK1; $p=0.10)$, phosphoinositide3-kinase regulatory subunit $2(P I K 3 R 2 ; p=0.10)$, and Ras homolog mTOR1 binding (RHEB; $p=0.15)$ tended to be or were downregulated in HT explants. In addition, Cyclin D1 $(C C N D 1 ; p=0.06)$ and TEA domain transcription factor 4 (TEAD4; $p=0.15)$ tended to be upregulated in HT explants during the mammary redevelopment phase of the dry period.

\subsection{Effects of In Vitro Treatments on Mammary Gland Gene Expression}

The expression of several genes involved in PRL and E signalling was impacted by our in vitro treatments during mammary involution, whereas no genes involved in PRL and E signalling were impacted during the mammary redevelopment phase. More specifically, casein beta (CSN2; $p=0.10)$, HRAS proto-oncogene, GTPase (HRAS; $p=0.08)$, Raf-1 proto-oncogene, serine/threonine kinase (RAF1; $p=0.04)$, suppressor of cytokine signaling 2 (SOCS2; $p=0.05$ ), Signal Transducers and Activators of Transcription 1 (STAT1; $p=0.12$ ) and Signal Transducers and Activators of Transcription $3($ STAT3; $p=0.04$ ) were or tended to be downregulated in explants cultured in $C$ media relative to when explants are cultured in B media. All of these aforementioned genes were also downregulated in explants cultured in $\mathrm{H}$ media relative to when explants were cultured in B media. However, only SOCS2 $(p=0.05)$ and STAT3 $(p=0.05)$ were significantly downregulated. In addition, BRAF ( $p=0.01)$, oestrogen receptor 1 (ESR1; $p=0.10), \operatorname{ESR2}(p=0.02), \mathrm{G}$ protein-coupled oestrogen receptor (GPER1; $p=0.12)$, Mitogen-activated protein kinase 1 $(M A P 2 K 1 ; p=0.06)$, and mitogen-activated protein kinase $1(M A P K 1 ; p=0.04)$ (all involved in $\mathrm{E}$ signalling) genes were or tended to be downregulated in explants cultured in $\mathrm{C}$ media relative to explants cultured in B media. Of these genes, BRAF ( $p=0.01), M A P 2 K 1(p=0.06)$, and MAPK1 were also downregulated, whereas ESR2 was upregulated in explants cultured in $\mathrm{H}$ media compared to explants cultured in B media (Figure 5c). 
a)

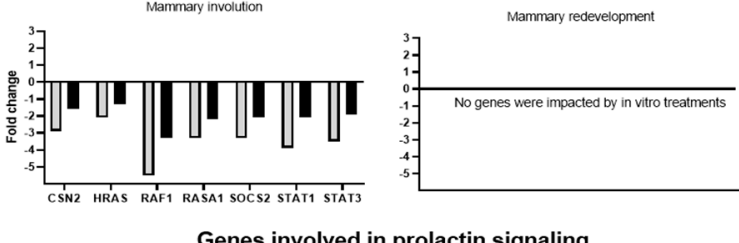

c)

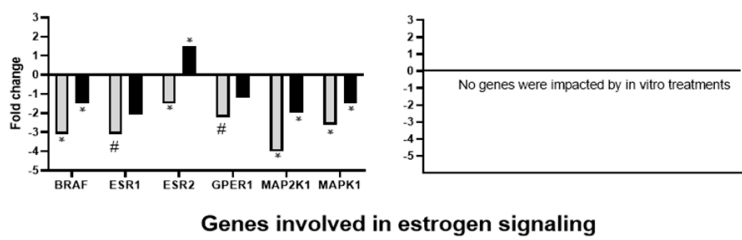

e)

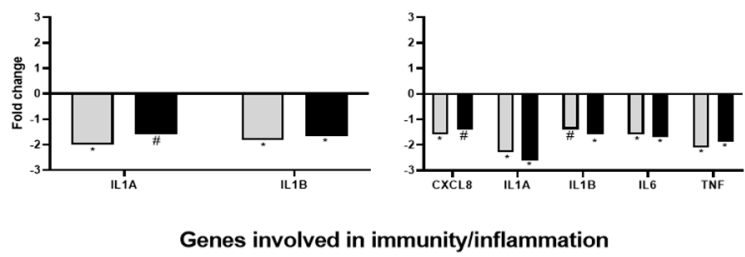

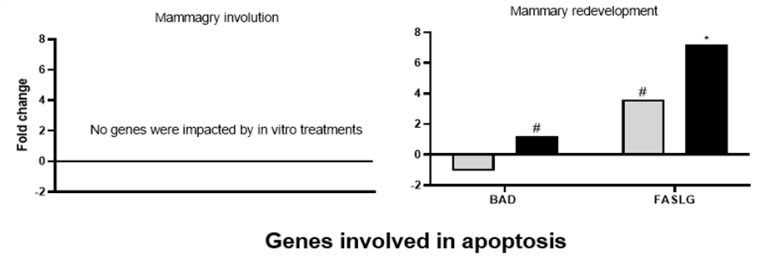

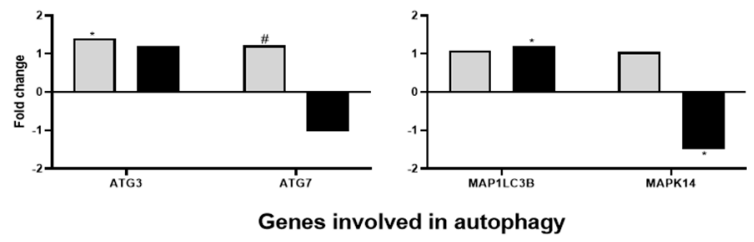

f)
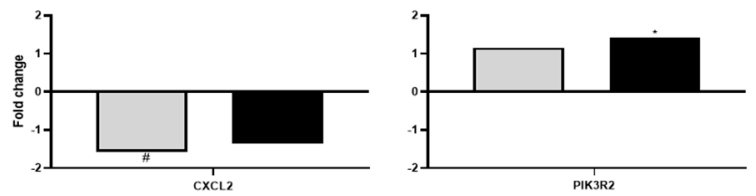

Genes involved in proliferation

Figure 5. Expression of genes involved in Prolactin (PRL) and oestrogen (E) signalling, cell apoptosis in tissue explants of mammary gland incubated in 3 different media: (1) Basal (B): no PRL or E; (2) Cooled-mimic (C): B $+20 \mathrm{ng} / \mathrm{mL}$ $\mathrm{PRL}+5.8 \mathrm{ng} / \mathrm{mL}$ E or (3) Heat stress-mimic $(\mathrm{H}): \mathrm{B}+40 \mathrm{ng} / \mathrm{mL}$ PRL + $2.9 \mathrm{ng} / \mathrm{mL}$ E. Explants were collected during early involution ( $3 \mathrm{~d}$ after dry off) and during mammary growth phases ( $35 \mathrm{~d}$ after dry off). Gene expression in mammary gland tissue explants is reported as fold change $\left(2^{-\Delta \Delta C t}\right)$ relative to B media. Grey bars indicate $C$ fold change and black bars indicate $\mathrm{H}$ fold change. An asterisk $\left({ }^{*}\right)$ indicates significant differences $(p \leq 0.05)$ and $(\#)$ indicates tendencies $(0.05<p \leq$ 0.15) between C (light grey bars) and B and HT (solid black bars) and B media. (a-f) refer to gene function.

Out of the 13 apoptosis-related genes (Figure $5 \mathrm{~b}$ ) and of the 11 autophagy-related genes (Figure 5d) analysed, only the mRNA abundance of BCL2-associated agonist of cell death $(B A D)$, Fas-Ligand (FASLG), autophagy-related ATG3 (ATG3), autophagy-related ATG7 (ATG7), microtubule-associated protein 1 light chain 3 beta (MAP1LC3B), and mitogenactivated protein kinase 14 (MAPK14) were impacted by the in vitro treatments. More specifically, during mammary involution, autophagy-related genes autophagy-related ATG3 ( $p=0.03)$ and autophagy-related ATG7 ( $p=0.07)$ were or tended to be upregulated in explants cultured in $C$ media relative to explants cultured in B media. During the mammary redevelopment phase of the dry period, BAD $(p=0.14)$, FASLG $(p=0.02)$, and $M A P 1 L B 3 B(p=0.04)$ were or tended to be upregulated in explants cultured in H media relative to explants cultured in B media, whereas MAPK14 $(p=0.02)$ was downregulated. In addition, FASLG tended to be upregulated in explants cultured in $C$ media relative to explants cultured in B media.

Out of the 22 genes involved in cell proliferation that were measured, only two were impacted by in vitro treatment (Figure 5f). During mammary involution, chemokine ligand 2 (CXCL2) tended to be downregulated $(p=0.14)$ in explants cultured in $C$ media relative to explants cultured in B media. During the mammary redevelopment phase of the dry period, phosphoinositide-3-kinase regulatory subunit $2(P I K 3 R 2 ; p=0.02)$ was upregulated in explants cultured in $\mathrm{H}$ media relative to explants cultured in $\mathrm{B}$ media.

Furthermore, 5 out of the 11 immune-related genes were impacted by the in vitro treatments (Figure 5e). During mammary involution, interleukin 1 alpha (IL1A; $p=0.08)$ and interleukin 1 beta $(I L 1 B ; p=0.01)$ tended to be or were downregulated in explants cultured in $\mathrm{C}$ and $\mathrm{H}$ media relative to explants cultured in B media. During mammary redevelopment, $\mathrm{C}-\mathrm{X}-\mathrm{C}$ motif chemokine ligand 8 (CXCL8; $p=0.07), \operatorname{IL1} A(p<0.001)$, IL1B $(p=0.06)$, interleukin $6($ IL6; $p=0.01)$, and tumor necrosis factor alpha $(T N F ; p=0.01)$ were 
or tended to be downregulated in explants cultured in $\mathrm{C}$ and $\mathrm{H}$ media relative to explants cultured in B media.

\subsection{Interactions between In Vivo and In Vitro Treatments}

A significant interaction between in vivo and in vitro treatments was identified for 8 out of 91 targeted genes (Table 1). For example, during mammary involution, BRAF and $E S R 2$, which are involved in E signalling, displayed a significant (both $p=0.03$ ) interaction between the in vivo and in vitro treatments. During the redevelopment phase of the dry period, hydroxysteroid 17-beta dehydrogenase 6 (HSD17B6; E signalling), caspase 8 (CASP8; apoptosis), MAP1LC3B (autophagy), lipopolysaccharide binding protein (LBP; inflammation), vascular endothelial growth factor (VEGFA; morphology), and PIK3R2 (cell proliferation) displayed a significant interaction between the in vivo and in vitro treatments.

Table 1. Relative gene expression of mammary gland tissue explants collected during involution and mammary redevelopment of the dry period in cows that were either cooled (shade, fans and soakers) or heat-stressed (only shade). Tissue explants were incubated in vitro in media with different hormone concentrations: Basal media: no prolactin (PRL), no estrogen (E); media $\mathrm{C}$ that mimics the hormone combination of cooled cows: Basal + low PRL + high E; media $\mathrm{H}$ that mimics hormone combination of heat-stressed cows: Basal + high PRL + low E. Relative gene expression is expressed as a fold change compared with Basal media.

\begin{tabular}{|c|c|c|c|c|c|c|}
\hline & \multirow[b]{2}{*}{ Genes ${ }^{1}$} & \multicolumn{2}{|c|}{ In Vivo-Cooled Cows } & \multicolumn{2}{|c|}{ In Vivo Heat-Stressed Cows } & \multirow[b]{2}{*}{$p$ Value } \\
\hline & & C-Fold Change & H-Fold Change & C-Fold Change & H-Fold Change & \\
\hline \multicolumn{7}{|l|}{ Early involution } \\
\hline \multicolumn{7}{|l|}{ E signalling } \\
\hline & $B R A F$ & -1.13 & -1.10 & -9.32 & -2.39 & 0.03 \\
\hline & ESR2 & 1.03 & 1.04 & -2.59 & 1.89 & 0.03 \\
\hline \multicolumn{7}{|c|}{ Mammary growth } \\
\hline \multirow{2}{*}{\multicolumn{7}{|c|}{ HSD17B6 }} \\
\hline & & & & & & \\
\hline & CASP8 & -1.38 & -1.06 & 1.36 & 1.24 & 0.06 \\
\hline \multicolumn{7}{|l|}{ Autophagy } \\
\hline & $M A P 1 L C 3 B$ & 1.12 & 1.82 & 1.13 & 1.03 & 0.08 \\
\hline \multicolumn{7}{|l|}{ Inflammation } \\
\hline & $L B P$ & -1.09 & 1.33 & 1.37 & -1.05 & 0.01 \\
\hline \multirow{2}{*}{ Proliferation } & VEGFA & 1.31 & 1.06 & -1.35 & 1.34 & 0.08 \\
\hline & PIK3R2 & 1.12 & 1.82 & 1.18 & 1.11 & 0.05 \\
\hline
\end{tabular}

${ }^{1}$ Only includes target genes with significant $(p<0.05)$ interactions or tendencies $(0.05<p<0.15)$ towards an interaction between in vivo and in vitro treatments.

\section{Discussion}

In the mammary gland, pro-apoptotic and autophagic signalling factors are triggered after the cessation of milk removal during the early phase of the dry period (involution), whereas the mammary redevelopment phase is characterized by upregulation of proliferation related genes [34]. Any disturbances in these cellular processes may severely impede the mammary gland's ability to synthesize milk in the subsequent lactation. During the past ten years, it has been well documented that dry period exposure of dairy cows to heat stress negatively impacts the next lactation (reviewed by Ouellet et al. [9]). Herein, we aimed to gain a better understanding of the underlying mechanisms for the observed impairments after dry period heat stress, by studying the mammary gene expression related to PRL and E pathways and key cellular process pathways under different thermal environments and hormonal milieus.

Temperature-humidity index measurements indicated that both CL and HT cows were under similar thermal environmental conditions during late gestation. The increase in 
vaginal temperature and respiratory frequency suggested that HT cows were not effective in maintaining euthermia and that the cooling system of fans and soakers was effective in alleviating heat stress in CL cows. Thus, in vivo treatments were properly induced in the current study. The quantification of LDH activity confirmed that the in vitro protocol (i.e., incubation time, temperature and hormonal concentrations) applied to mammary tissue explants was appropriate to maintain tissue viability. Therefore, our mammary tissue explants were a suitable experimental model to study hormonal mechanisms induced by heat stress.

Principal component analysis is often used to transform original dependent variables into new uncorrelated dimensions to simplify data structure, eliminate descriptor redundancies, and indicate potential latent causal variables [35]. In the current study, PCA was applied to the normalized relative gene expression to simplify the interpretation of data. As the first two PC accounted for explained $60 \%$ of total variation when the statistical analysis of differences in gene expression was performed by biopsy time point separately, further analysis was conducted by biopsy time separately. Therefore, the PCA gave insight on how to structure the data analysis given the complexity of the experimental design.

In the present study, the in vivo-imposed heat stress significantly influenced the expression of PRLR long and ESR2 genes in mammary tissue explants during mammary involution. Previous studies have reported that heat stress induced during the dry period decreases E and increases PRL in plasma when compared to cows in thermoneutral or cool conditions [15-17]. The exact reason why heat stress modulates PRL and E remains unknown. Research suggests that the increase in PRL under heat stress may be associated with the sweating response, the induction of heat shock proteins and pelage molting, all mechanisms expected to improve heat loss capacity [36]. Our results show that heat stress alters the expression of PRL and E receptors in the mammary gland relative to cool conditions, suggesting that heat stress during the dry period changes the responsiveness of the mammary cells to E and PRL. Notably, the most pronounced PRL-induced gene in mammary tissue, casein beta (CSN2) [37], was not differentially expressed due to in vivo treatments in the current study. This result is not in accordance with Fabris et al. [23] who reported that CSN2 was upregulated in cows exposed to HT during the late dry period. The discrepancy may be attributed to the differed timing of mammary biopsies. However, our findings are in accordance with Corazzin et al. [38], who reported similar levels of CSN2 in milk somatic cells (representative of mammary tissue) of lactating cows exposed to thermoneutral conditions and then mild heat stress.

Emerging evidence indicates that PRL and E modifications have the potential to alter key cellular processes, such as apoptosis and autophagy occurring during the mammary dry period. Apoptosis and autophagy are important mechanisms for mammary epithelial cell death, and consequently, for cell renewal throughout the dry period [6,20]. Prolactin was shown to decrease mammary cell apoptosis in vitro by optimizing the action of IGF-1, a growth factor, through downregulation of IGFBP5 gene expression [6] and E positively regulates autophagy in vitro in bovine mammary epithelial cells, likely via membranebound receptors [39]. In the current study, in vivo heat stress significantly impacted apoptosis and autophagy pathways during mammary involution, which is consistent with previous studies from our laboratory $[7,21,23]$. However, heat stress had no significant effect on IGFBP5 expression during mammary involution, but it tended to be upregulated in HT explants during the mammary redevelopment phase of the dry period, which could be associated with disturbed cell proliferation as calving approaches. Furthermore, this could potentially indicate that PRL may modulate apoptosis in vivo in more than one way. Herein, no heat shock protein (HSP) genes were significantly impacted by the imposed in vivo treatments. However, this was expected as HSP related genes are associated with acute heat stress, whereas the animals of the current study were exposed to chronic heat stress [40]. Heat shock proteins act as molecular chaperones to assist protein folding under heat stress conditions and interfere with major apoptotic pathways to protect cells from hyperthermia [40,41]. Moreover, recent investigations have also demonstrated an inverse 
relationship between the induction of HSP70 and autophagy induction in human cells [42]. Collectively, in the current study, most genes related to apoptosis and autophagy that were significantly impacted by in vivo heat stress were downregulated in HT explants relative to CL explants during early involution. However, those genes were upregulated during mammary redevelopment which lends credence to the hypothesis that heat stress may alter the trajectory of apoptosis and autophagy in mammary tissue explants during early involution and even during the late dry period.

In contrast to the involution period, the mammary redevelopment phase is characterised by rapid cell proliferation. In the present study, most proliferation-related genes analysed were not different between in vivo treatments. However, the few that were differentially expressed were downregulated in HT explants relative to CL explants during mammary involution, then surprisingly upregulated during mammary redevelopment (i.e., CCDN1, TEAD4). Therefore, our results could potentially indicate that apoptosis and autophagy are more impacted by heat treatments than cell proliferation, which is in line with recent findings of Fabris et al. [23].

Cessation of milking also induces the recruitment of immune cells and immune factors that in turn offer protection against inflammation [3]. In the present study, genes related to immunity and inflammation were upregulated in HT explants relative to CL explants during both mammary involution and redevelopment, indicative of compromised immunity and inflammation in HT cows throughout the dry period. Impaired immunity under heat stress was previously reported by Thompson and Dahl [43], who examined the impact of dry period season as a proxy for heat stress effects. Those authors reported that high ambient temperatures reduced the immune competence of cows, as dry periods corresponding to the summer months increased the incidence of mastitis, respiratory disease, and displaced abomasum. Furthermore, a porcine study demonstrates plausible triggering the inflammatory response under heat stress [44] whereby TNF intramuscular relative abundance was increased following $24 \mathrm{~h}$ of heat stress, possibly due to migration from the vasculature into tissues. In parallel, increased oxidative stress was also detected. Increased TNF expression or oxidative stress would ostensibly initiate an inflammatory response via $N F-\kappa B$, which could also be the case in the current study, as NFK relative abundance was increased in HT explants.

Irrespective of the in vivo treatments, in vitro treatment that mimics the hormonal responses of heat-stressed or cooled cows also significantly affected the expression of several genes encompassing PRL and E signalling, apoptosis, autophagy, proliferation, immunity and inflammation pathways. Interestingly, the most significant effects of in vitro treatments were reported during mammary involution. Furthermore, relative to explants cultured in B media, which did not contain PRL and E, the majority of genes studied were downregulated in explants cultured in $\mathrm{C}$ and $\mathrm{H}$ media. In fact, our results showed that the two in vitro treatments consisting of two different hormonal combinations similarly impacted the expression of STAT3, MAPK1, and MAP2K1 (that regulate PRL and E signalling and cell survival pathway), SOCS2 and BRAF genes (that regulate PRL signalling and apoptosis pathway), and IL1A, IL1B (immunity pathway) during mammary involution. Furthermore, expression of CSN2, HRAS, RAF1, STAT1 (all involved in PRL signalling), ESR1, ESR2, GPER1 (involved in E signalling), ATG3, ATG7 (both involved in autophagy) and CXCL2 (cell survival) were impacted differently by the different hormonal combinations tested in vitro. Since mammary involution is hallmarked by intense cellular turnover due to increases in apoptosis and autophagy [45] and immune cell recruitment [3], we speculate that the interaction between these changes in gene expression has different impacts on the apoptotic, autophagic, and proliferative rates of the $\mathrm{H}$ and $\mathrm{C}$ treatments thereby resulting in different lactational performance in the subsequent lactation. It is noteworthy to mention that no apoptosis-related gene was impacted by the tested in vitro treatment during mammary involution. This could potentially indicate that other mechanisms besides PRL and $\mathrm{E}$ alterations may modulate apoptosis in the early dry period. 
Relative to mammary involution, fewer genes were impacted by the in vitro treatments tested during the mammary redevelopment phase of the dry period. Interestingly, the expression of genes related to immunity and inflammation was downregulated irrespective of the culture media ( $\mathrm{C}$ or $\mathrm{H})$, indicating that PRL and $\mathrm{E}$ hormonal alterations may impact these pathways in a permissive manner. Prepartum heat exposure was previously reported to depress immune function and evidence links this decrease to altered PRL signalling under heat stress [46]. Our results lend credence to this hypothesis. Moreover, $\mathrm{H}$ and $\mathrm{C}$ in vitro treatments differently affected gene expression of $B A D$ (apoptosis pathway) and MAPK14 (autophagy pathway), which potentially indicates that change in relative levels of mammogenic hormones under heat stress may disturb autophagy and apoptosis as calving approaches, which may have repercussions during lactation.

\section{Conclusions}

Our results confirmed that exposure to heat stress during the last six weeks of gestation impacts mammary gland expression of genes involved in PRL and E signalling, apoptosis, autophagy, proliferation, immunity and inflammation. Furthermore, we demonstrated that our in vitro treatments that mimic the hormonal responses of heat-stressed or thermoneutral cows also significantly affected the expression of several genes encompassing PRL and E signalling, apoptosis, autophagy, proliferation, immunity and inflammation pathways. The fact that several genes encompassing key cellular processes were impacted differently by the two in vitro treatments may indicate that PRL and E alterations can modulate the production impairments caused by late-gestation heat stress. However, that several genes were impacted in a similar manner or not impacted by the in vitro treatments suggests that there are likely additional contributing factors under dry period heat stress beyond the direct effects of PRL and E on mammary cell death and proliferation.

Supplementary Materials: The following are available online at https:/ /www.mdpi.com/2076-261 5/11/2/563/s1, Table S1: Primers used in quantitative real-Time PCR assay gene expression.

Author Contributions: V.O. conducted all data analysis and wrote the manuscript. J.N. and M.G.M. contributed to the data analysis. V.A.L. achieved the laboratory analysis. A.L.S., T.F.F., and B.D.-S. performed the farm work and mammary biopsies. J.L. and G.E.D. conceived the experiment and obtained the necessary funding. All authors have read and agreed to the published version of the manuscript.

Funding: Support was provided by USDA-National Institute for Food and Agriculture (Washington, DC; grant \#2015- 67015-23409) to GED.

Institutional Review Board Statement: This study was approved by the Institutional Animal Care and Use Committee at the University of Florida and was conducted at the University of Florida Dairy Unit (Hague, FL, USA).

Acknowledgments: The authors thank the staff of the Dairy Unit of University of Florida for animal care and data collection. Support was provided by USDA-National Institute for Food and Agriculture (Washington, DC; grant \#2015- 67015-23409) to GED.

Conflicts of Interest: The authors declare no conflict of interest.

\section{References}

1. Capuco, A.V.; Akers, R.M.; Smith, J.J. Mammary growth in Holstein cows during the dry period: Quantification of nucleic acids and histology. J. Dairy Sci. 1997, 80, 477-487. [CrossRef]

2. Capuco, A.V.; Ellis, S.E.; Hale, S.A.; Long, E.; Erdman, R.A.; Zhao, X.; Paape, M.J. Lactation persistency: Insights from mammary cell proliferation studies. J. Anim. Sci. 2003, 81 (Suppl. 3), 18-31. [CrossRef]

3. Hurley, W.L. Mammary Gland Function during Involution. J. Dairy Sci. 1989, 72, 1637-1646. [CrossRef]

4. Wilde, C.J.; Quarrie, L.H.; Tonner, E.; Flint, D.J.; Peaker, M. Mammary apoptosis. Livest. Prod. Sci. 1997, 50, 29-37. [CrossRef]

5. Sorensen, M.T.; Orgaard, J.V.N.; Theil, P.K.; Vestergaard, M.; Sejrsen, K. Cell turnover and activity in mammary tissue during lactation and dry period in dairy cows. J. Dairy Sci. 2006, 89, 4632-4639. [CrossRef]

6. Zarzyńska, J.; Gajkowska, B.; Wojewodzka, U.; Dymnicki, E.; Motyl, T. Apoptosis and autophagy in involuting bovine mammary gland is accompanied by up-regulation of TGF-beta1 and suppression of somatotropic pathway. Pol. J. Vet. Sci. 2007, 10, 1-9. [PubMed] 
7. Tao, S.; Bubolz, J.W.; do Amaral, B.C.; Thompson, I.M.; Hayen, M.J.; Johnson, S.E.; Dahl, G.E. Effect of heat stress during the dry period on mammary gland development. J. Dairy Sci. 2011, 94, 5976-5986. [CrossRef]

8. Tao, S.; Thompson, I.M.; Monteiro, A.P.A.; Hayen, M.J.; Young, L.J.; Dahl, G.E. Effect of cooling heat-stressed dairy cows during the dry period on insulin response. J. Dairy Sci. 2012, 95, 5035-5046. [CrossRef] [PubMed]

9. Ouellet, V.; Laporta, J.; Dahl, G.E. Late gestation heat stress in dairy cows: Effects on dam and daughter. Theriogenology 2020, 150, 471-479. [CrossRef]

10. Beardsley, G.L.; Muller, L.D.; Garverick, H.C.; Ludens, F.C.; Tucker, W.L. Initiation of parturition in dairy cows with dexamethasone. II. Response to dexamethasone in combination with estradiol benzoate. J. Dairy Sci. 1976, 59, 241-247. [CrossRef]

11. Bremmer, D.R.; Christensen, J.O.; Grummer, R.R.; Rasmussen, F.E.; Wiltbank, M.C. Effects of induced parturition and estradiol on feed intake, liver triglyceride concentration, and plasma metabolites of transition dairy cows. J. Dairy Sci. 1999, 82, 1440-1448. [CrossRef]

12. Do Amaral, B.C.; Connor, E.E.; Tao, S.; Hayen, M.J.; Bubolz, J.W.; Dahl, G.E. Heat-stress abatement during the dry period: Does cooling improve transition into lactation? J. Dairy Sci. 2009, 92, 5988-5999. [CrossRef]

13. Fabris, T.F.; Laporta, J.; Skibiel, A.L.; Corra, F.N.; Senn, B.; Wohlgemuth, S.E.; Dahl, G.E. Effect of heat stress during early, late, and entire dry period on dairy cattle. J. Dairy Sci. 2019, 02, 5647-5656. [CrossRef]

14. Lough, D.S.; Beede, D.L.; Wilcox, C.J. Effects of feed intake and thermal stress on mammary blood flow and other physiological measurements in lactating dairy cows. J. Dairy Sci. 1990, 3, 325-332. [CrossRef]

15. Collier, R.J.; Doelger, S.G.; Head, H.H.; Thatcher, W.W.; Wilcox, C.J. Effects of Heat Stress during Pregnancy on Maternal Hormone Concentrations, Calf Birth Weight and Postpartum Milk Yield of Holstein Cows. J. Anim. Sci. 1982, 54, 309-319. [CrossRef]

16. Do Amaral, B.C.; Connor, E.E.; Tao, S.; Hayen, M.J.; Bubolz, J.W.; Dahl, G.E. Heat stress abatement during the dry period influences prolactin signaling in lymphocytes. Domest. Anim. Endocrinol. 2010, 38, 38-45. [CrossRef] [PubMed]

17. Do Amaral, B.C.; Connor, E.E.; Tao, S.; Hayen, M.J.; Bubolz, J.W.; Dahl, G.E. Heat stress abatement during the dry period influences metabolic gene expression and improves immune status in the transition period of dairy cows. J. Dairy Sci. 2011, 94, 86-96. [CrossRef] [PubMed]

18. Accorsi, P.; Pacioni, B.; Pezzi, C.; Forni, M.; Flint, D.; Seren, E. Role of Prolactin, Growth Hormone and Insulin-Like Growth Factor 1 in Mammary Gland Involution in the Dairy Cow. J. Dairy Sci. 2002, 85, 507-513. [CrossRef]

19. Connor, E.; Meyer, M.; Li, R.; Van Amburgh, M.; Boisclair, Y.; Capuco, A. Regulation of Gene Expression in the Bovine Mammary Gland by Ovarian Steroids. J. Dairy Sci. 2007, 90 (Suppl. 1), E55-E65. [CrossRef]

20. Sobolewska, A.; Gajewska, M.; Zarzyńska, J.; Gajkowska, B.; Motyl, T. IGF-I, EGF, and sex steroids regulate autophagy in bovine mammary epithelial cells via the mTOR pathway. Eur. J. Cell Biol. 2009, 88, 117-130. [CrossRef] [PubMed]

21. Wohlgemuth, S.E.; Ramirez-Lee, Y.; Tao, S.; Monteiro, A.P.A.; Ahmed, B.M.; Dahl, G.E. Short communication: Effect of heat stress on mammary gland autophagy during the dry period. J. Dairy Sci. 2016, 99, 4875-4880. [CrossRef] [PubMed]

22. Fabris, T.F.; Skibiel, A.L.; Laporta, J.; McLean, D.J.; Kirk, D.J.; Chapman, J.D.; Dahl, G.E. Heat stress and OmniGen-AF alter mammary gland gene expression and endocrine responses in the dry period. J. Dairy Sci. 2018, 101 (Suppl. 2), 69.

23. Fabris, T.F.; Laporta, J.; Skibiel, A.L.; Senn, B.; Wohlgemuth, S.E.; Dahl, G.E. Effect of heat stress during the early and late dry period on mammary gland development of Holstein dairy cattle. J. Dairy Sci. 2020, 103, 8576-8586. [CrossRef]

24. NRC. Nutrient Requirements of Dairy Cattle, 7th ed.; National Academies Press: Washington, DC, USA, 2001.

25. NRC. A Guide to Environmental Research on Animals; National Academy of Sciences: Washington, DC, USA, 1971.

26. Dikmen, S.; Hansen, P. Is the temperature-humidity index the best indicator of heat stress in lactating dairy cows in a subtropical environment? J. Dairy Sci. 2009, 92, 109-116. [CrossRef] [PubMed]

27. Dado-Senn, B.; Vega Acosta, L.; Torre Riviera, M.; Field, S.L.; Marrero, M.G.; Davison, B.D.; Tao, S.; Fabris, T.F.; Ortiz-Colón, G.; Dahl, G.E.; et al. Pre- and postnatal heat stress abatement affects dairy calf thermoregulation and performance. J. Dairy Sci. 2020, 103, 4822-4837. [CrossRef]

28. Skibiel, A.L.; Dado-Senn, B.; Fabris, T.F.; Dahl, G.E.; Laporta, J. In utero exposure to thermal stress has long-term effects on mammary gland microstructure and function in dairy cattle. PLoS ONE 2018, 13, e0206046. [CrossRef] [PubMed]

29. De Vries, L.; Casey, T.; Dover, H.; VandeHaar, M.; Plaut, K. Effects of transforming growth factor- $\beta$ on mammary remodeling during the dry period of dairy cows. J. Dairy Sci. 2011, 94, 6036-6046. [CrossRef] [PubMed]

30. Tao, S.; Monteiro, A.; Thompson, I.; Hayen, M.; Dahl, G. Effect of late-gestation maternal heat stress on growth and immune function of dairy calves. J. Dairy Sci. 2012, 95, 7128-7136. [CrossRef] [PubMed]

31. Marrero, M.G.; Field, S.L.; Skibiel, A.L.; Dado-Senn, B.; Driver, J.P.; Laporta, J. Increasing serotonin bioavailability alters gene expression in peripheral leukocytes and lymphoid tissues of dairy calves. Sci. Rep. 2020, 10, 9712. [CrossRef] [PubMed]

32. Macciotta, N.; Gaspa, G.; Steri, R.; Nicolazzi, E.; DiMauro, C.; Pieramati, C.; Cappio-Borlino, A. Using eigenvalues as variance priors in the prediction of genomic breeding values by principal component analysis. J. Dairy Sci. 2010, 93, 2765-2774. [CrossRef]

33. Livak, K.J.; Schmittgen, T.D. Analysis of relative gene expression data using real-time quantitative PCR and the $2-\Delta \Delta \mathrm{Ct}$ method. Methods 2011, 25, 402-408. [CrossRef] [PubMed]

34. Dado-Senn, B.; Skibiel, A.L.; Fabris, T.F.; Zhang, Y.; Dahl, G.E.; Peñagaricano, F.; LaPorta, J. RNA-Seq reveals novel genes and pathways involved in bovine mammary involution during the dry period and under environmental heat stress. Sci. Rep. 2018, 8 , 11096. [CrossRef] 
35. Chapman, K.W.; Lawless, H.T.; Boor, K.J. Quantitative Descriptive Analysis and Principal Component Analysisfor Sensory Characterization of Ultrapasteurized Milk. J. Dairy Sci. 2001, 84, 12-20. [CrossRef]

36. Baumgard, L.H.; Rhoads, R. Effects of Heat Stress on Postabsorptive Metabolism and Energetics. Annu. Rev. Anim. Biosci. 2013, 1, 311-337. [CrossRef] [PubMed]

37. Bole-Feysot, C.; Goffin, V.; Edery, M.; Binart, N.; Kelly, P.A. Prolactin (PRL) and its receptor: Actions, signal transduction path-ways and phenotypes observed in PRL receptor knockout mice. Endocr. Rev. 1998, 19, 225-268. [CrossRef] [PubMed]

38. Corazzin, M.; Saccà, E.; Lippe, G.; Romanzin, A.; Foletto, V.; Da Borso, F.; Piasentier, E. Effect of Heat Stress on Dairy Cow Performance and on Expression of Protein Metabolism Genes in Mammary Cells. Animals 2020, 10, 2124. [CrossRef] [PubMed]

39. Sobolewska, A.; Elminowska-Wenda, G.; Bogucka, J.; Szpinda, M.; Walasik, K.; Bednarcyk, M.; Paruszewska-Actel, M. Myogenesis-Possibilities of its stimulation in chickens. Folia Biol. 2011, 59, 85-90. [CrossRef]

40. Lanneau, D.; De Thonel, A.; Maurel, S.; Didelot, C.; Garrido, C. Apoptosis Versus Cell Differentiation: Role of heat shock protein HSP90, HSP70 and HSP27. Prion 2007, 1, 53-60. [CrossRef]

41. Collier, R.J.; Dahl, G.E.; Van Baale, M.J. Major advances associated with environmental effects on dairy cattle. J. Dairy Sci. 2006, 89, 1244-1253. [CrossRef]

42. Kanninen, T.T.; Sisti, G.; Witkin, S.S. Induction of the $70 \mathrm{kDa}$ heat shock protein stress response inhibits autophagy: Possible consequences for pregnancy outcome. J. Matern. Fetal Neonatal Med. 2016, 29, 159-162. [CrossRef]

43. Thompson, I.M.; Dahl, G.E. Dry period seasonal effects on the subsequent lactation. Prof. Anim. Sci. 2012, 28, 628-631. [CrossRef]

44. Montilla, S.I.R.; Johnson, T.P.; Pearce, S.C.; Gardan-Salmon, D.; Gabler, N.K.; Ross, J.W.; Rhoads, R.P.; Baumgard, L.H.; Lonergan, S.M.; Selsby, J.T. Heat stress causes oxidative stress but not inflammatory signaling in porcine skeletal muscle. Temperature 2014, 1, 42-50. [CrossRef] [PubMed]

45. Singh, K.; Vetharaniam, I.; Dobson, J.; Prewitz, M.; Oden, K.; Murney, R.; Swanson, K.; McDonald, R.; Henderson, H.; Stelwagen, K. Cell survival signaling in the bovine mammary gland during the transition from lactation to involution. J. Dairy Sci. 2016, 99, 7523-7543. [CrossRef]

46. Tao, S.; Dahl, G. Invited review: Heat stress effects during late gestation on dry cows and their calves. J. Dairy Sci. 2013, 96, 4079-4093. [CrossRef] [PubMed] 